\title{
Editorial
}

\section{Introduction to the special issue: The changing use and misuse of khat (Catha edulis)-Tradition, trade and tragedy}

\begin{abstract}
A B S T R A C T
Within the last decade the hitherto little known psychoactive substance of khat has emerged as a regional and international issue. In the Horn of Africa khat production has spurred an economic boom, but dramatic increases in consumption have raised public health concerns. Given the complexity of the topic spanning multiple academic disciplines and fields of professional practice, the need for a systematic overview is urgent. To facilitate the exchange of information, prompt interdisciplinary research and alert international organisations and governments, the authors organised an international and interdisciplinary khat conference in 2009. This special issue of the Journal of Ethnopharmacology contains articles written by different conference speakers that present the current state of knowledge and the challenges for future research and politics.
\end{abstract}

(C) 2010 Published by Elsevier Ireland Ltd.

The young leaves and shoots of the khat tree (Catha edulis) have been consumed for centuries in the countries of the Horn of Africa, the southern parts of the Arabian peninsula and in the Kenyan highlands, in what is becoming known as the khat belt.

Until the early 20th century khat remained a niche crop restricted to the peoples in and adjacent to the production areas. Early European travelers to Arabia Felix (Yemen) or Ethiopia only began to take notice of khat use at the end of the 18th century (Krikorian, 1984). Since then, and particularly over the last four decades, khat has become an inescapable fact of social reality in the khat belt and beyond. The lives of people in Djibouti known as 'khateur', a considerable segment of the male adult population, revolve around a rhythm of khat deliveries, purchases and chewing sessions. Such demand is both cause and consequence of an unparalleled boom in khat production, driven largely, and in contrast to other cash crop such as coffee, by the regional market. Rough estimates suggest a market in excess of 10 millions daily across the khat belt where khat is produced and traded as a legal commodity.

This rise of khat is closely linked with rational decisions of farmers and business opportunities for petty traders as well as with migration flows. Thus, production, trade and use are moving from traditional khat countries to the neighboring regions, including Uganda, Rwanda and South Africa. The economic consequences have secured the livelihoods of millions in one of the poorest region in the globe. At the same time the costs of untrammeled production and poorly regulated consumption require closer attention. The exploitation of water resources in Yemen, where underground aquifers are being depleted at an alarming rate, and deforestation on some parts of Ethiopia are indicative of looming ecological problems closely related to khat production (Almas and Scholz, 2006; Dessie and Kinlund, 2007). In parts of Ethiopia, Kenya and Yemen farmers switch from growing food crops to khat, with potential implications for food security (GermanAgroAction, 2009), while in
Djibouti some of the poor are reported to prioritize khat over food purchases (Milanovic, 2008). Further concerns crystallize around the implications of widespread khat use for public health, both as a result of chronic consumption and substitution effects (Feyissa and Kelly, 2008). Despite the fact that khat has been put on the agenda of international drug control organizations since 1930s, the issue only came to larger international attention when reported in the context of the UN mission in Somalia (UNOSOM) (Randall, 1993), and secondly as an emerging phenomenon among the growing populations of immigrants from the khat belt in Europe and North America where it raised fears over potential for abuse (EMCDDA, in press).

At present the debate pivots on quest for an appropriate regulatory regime that strikes a balance between economic benefit, public health costs and ecological ramification.

\section{The regulation of khat use}

In most societies, the history of psychoactive substance use is closely interwoven with wider regimes of social control and regulation. Complications arise with the arrival of new substances, or when patterns of use change dramatically (Watzl and Singer, 2005).

One well-known example from the early modern period is the London Gin craze of the early 18th century. Though alcohol distillation had been known for several centuries a combination of factors, including the availability of raw materials and sudden demand from the newly forming class of industrial workers and rural migrants disposed by land enclosures, led to sharp increase in gin consumption between 1685 and 1750 (Watzl and Singer, 2005). Public concern found expression in the first modern public health campaign, spearheaded by William Hogarth's famous engravings and Henry Fielding's prose drawing attention to the drastic socioeconomic and health consequences among the poor. A slough of interventions aimed at reducing consumption including taxation 
increases, the licensing of sales outlets, and the restrictions of debt collection sparked violent reactions, including rioting after the passage of the 1736 Gin Act. Consumption fell towards the mid century, attributed to a succession of poor wheat harvests and falling wages (Warner, 2002).

The London Gin Craze provides an insight into the reaction of modern societies to sudden increases in the consumption of psychoactive substances and allows us to draw some parallels with the process underway in the countries of the khat belt. In these countries sharp rises in the production and distribution as well as social changes have transformed the pattern and culture of consumption. Khat use has 'trickled down' to economically disadvantaged segments of the population, and has been detached from social occasions to be used casually and often individually. Governments have taken a laissez-fare approach, leaving the discussion on advantages and benefits, particularly with regard to health and social costs to civil society organisations. Although such efforts have repeatedly succeeded in bringing khat to the attention of local and national governments (Anderson et al 2007; Beckerleg, 2010), it remains to be seen whether such efforts will eventuate in legislation comparable to the Gin Acts of 1736 and 1751.

One pointer can be taken from Hogarth's complement to the apocalyptic havoc of Gin Alley. It is the vision of Beer Lane, depicting a scene of harmony and prosperity, based on the socially integrated consumption of beer, the mild alcoholic alternative. In the khat debate there are equally signs of an alternative to the advocates of ban and crop eradication on the one hand, and the proponents of a laissez faire regime on the other. A more moderate position is opening up, proposing measures to reduce any potential harms by regulating the production, distribution and use of khat.

\section{The changing discourse around khat}

Controversy around khat is probably as old as use itself. It has been condemned by the Ethiopian orthodox church (Anderson et al., 2007) and the more fundamentalist Islamic schools of thought particularly in Saudi Arabia (Al-Ghdaian, 1983). Islamic scholars in Yemen, Somalia and Ethiopia by contrast integrated khat use into religious life, including the study of the Holy Koran or to enhance religious experience as practiced by Sufi mystics (Gebissa, 2004; Schopen, 1981). During the colonial era, arguments about moral degeneration, falling economic productivity and the association with political unrest motivated official and largely unsuccessful bans on khat (Barre, 1983; Warfa et al., 2007).

The scientific discourse on khat shows similar fissures, usually along the lines of academic discipline. Medical and pharmacological research approached khat with the underlying assumption that it is analogous to other psychoactive drugs; consequently, for more than a decade pharmacological research focussed on the laboratory-based study of cathinone, the main psychoactive principle in the khat leaves. Anthropologists and social scientists, by contrast, stressed the cultural functions and traditional values in khat using societies. Much of the moral and religious arguments during the last century found themselves being reflected in the scientific discourse. For long, researchers from different disciplines remained in their isolated silos and found not opportunity to exchange information and develop a common position. Hence it was only in 1984 that the first international, interdisciplinary conference on khat could be organised (Shahandeh et al., 1983). Since then, thanks to the efforts of different scholars, some progress has been made in putting the scientific discourse at least on a more evidence-based footing. A wealth of new research has been produced across different fields, and there is a growing awareness of the need for interdisciplinary perspectives on so complex a topic. This evidence-based and unemotional attitude is more and more feeding back into the general khat discourse. But the WHO Expert Committee and other organizations who have reviewed khat recently (Advisory Council on the Misuse of Drugs, 2005; World Health Organization, 2006) and organizations who have formulated recommendations to deal with khat-related problems (The World Bank, 2007; World Health Organization Eastern Mediterranean Regional Office, 2007) noted that high quality studies are still rare. Too few human subject studies are being undertaken and, consequently, some developments are only mentioned by observational reports while other haven't even been accounted for in the international scientific literature.

\section{The 2009 international khat conference}

In this regard, the conference, taking place in October 2009 at Linköping, Sweden, was something of a milestone in the study of khat in particular, and in the study of mind-altering substances in general. Organised with the financial support and administrative backup of the European Science Foundation (http://www.esf.org/index.php?id=5160) it brought together sixty international researchers from anthropology, economy, geography, history, medicine, pharmacology, psychology and political science to discuss the current state of knowledge on khat. It can be called something like the first attempt to find an interdisciplinary khat research field. This Special Issue of JEP is dedicated to this conference and includes articles written by some of the key speakers.

In the first article, Al-Motarreb et al. (2010) review the evidence for khat as a causal factor for cardiovascular diseases and other internal medical problems. It is not surprising that in many aspects more research is needed in order to come to clear evidence.

Khamadeep Bhui and Nasir Warfa (Bhui and Warfa, 2010) contribute to the question whether khat use is linked to psychotic disorders by re-analyzing one of their studies among Somalis living in the UK. In contrast to studies from the Horn of Africa (Odenwald et al., 2009) they cannot find such a relationship and analyze the reasons for this discrepancy.

Hoffman and Al'Absi (2010) take up a very important topic that has not been studied so far: the neurobehavioral functions that might be impaired by chronic khat use. While this is clearly the case for amphetamine and cocaine, the authors develop suggestions how cognitive impairments and neurobehavioral dysfunctions can be studied and evaluated among khat users.

Al-Hebshi et al. (2010) contribute with an article that would have been called provocative some years ago: They study a possible positive medicinal effect of khat leaves. Their well-controlled study reports first evidence for a probiotic effect in the mouth of khat chewers. Studies like this are urgently needed for a balanced and empirical oriented evaluation of khat.

Kassim et al. (2010) contribute to the field of khat research by evaluating a common psycho-diagnostic screening questionnaire for drug dependence for khat research. They developed a psychometric research tool that can be used for the study of khat addiction.

Paul Griffiths and his colleagues from the European Monitoring Centre for Drugs and Drug Abuse (Griffiths et al., 2010), write about the difficulties of monitoring khat use in the European Community. They review the available data on khat use in Europe and analyze the current situation in the EC where khat is legal in some member countries and illegal in others. They stress that no reliable data exist on khat trade and use on a European level and argue that this situation needs to be changed.

Klein and Metal (2010) raise the question of what is the best way to regulate khat in the countries where it is a legal commodity. Their suggestions are surprisingly similar to what one would expect to be the case for any culturally sanctioned substance with a potential for harm. 
In a contribution from political economy, Hansen (2010) evaluates the impact of khat use on the political situation in Somaliland, the North-Eastern part of Somalia, where khat abuse is most evident today. In his article he argues that the meaning of khat is ambiguous, contributing to the political stability and instability of this self-declared state.

Susan Beckerleg's topic of research is the popular discourse on khat in East Africa (Beckerleg, 2010). In her contribution she reports on how khat is commonly associated with male sexual (dys)functions, female sexual lapse and prostitution as well as moral decay. She unmasks that sensationalist media reports and the general male attitudes are in many ways unsubstantiated by empirical evidence.

What will be the future of khat? Will it be another internationally traded illegal commodity? In his perspective article Gebissa (2010) reviews the evidence in favor and against such a development. He believes that khat will have a stable regional appearance but will not turn out to be an internationally traded drug. This will not make it necessary to push international scheduling.

Odenwald and colleagues try to answer the question why khat use cannot be eradicated, but why it should be regulated and why this has not yet happened (Odenwald et al., 2010). They argue that a detailed and empirically founded consensus is needed on harms and benefits that should be the base of a series of international and regional conferences.

This Special Issue demonstrates that the current understanding of many khat-related topics is still poor and that further research is urgently needed. Especially interdisciplinary studies, crossing the gap between laboratory and field research are missing. We hope that this Special Issue will contribute to further develop the interdisciplinary khat research field. Equally we want to encourage national governments and international agencies to take up the topic.

We thank the European Science Foundation, the German Federal Foreign Office and the University of Konstanz for their support of the conference and this Special Issue.

\section{References}

Al-Ghdaian, A.A., 1983. Khat in the Shari'ah (islamic law). Paper presented at the International conference on khat: the health and socio-economic aspects of khat use, Antananaribo, Madagascar.

Al-Hebshi, N.N., Al-Sharabi, A.K., Shuga-Aldin, H.M., Al-Haroni, M., Ghandour, I., 2010. Effect of khat chewing on periodontal pathogens in subgingival biofilm from chronic periodontitis patients. Journal of Ethnopharmacology.

Al-Motarreb, A., Al-Habori, M., Broadley, K.J., 2010. Khat chewing, cardiovascular diseases and other internal medical problems: the current situation and directions for future research. Journal of Ethnopharmacology.

Almas, A.A.M., Scholz, M., 2006. Agriculture and water resources crisis in Yemen: need for sustainable agriculture. Journal of Sustainable Agriculture 28 (3), 55-75.

Anderson, D., Beckerleg, S., Hailu, D., Klein, A., 2007. The Khat Controversy: Stimulating the Debate on Drugs. Oxford: Berg.

Barre, S., 1983. Inaugural speech of H.E. President of SDR. Paper presented at the Report of the WHO intercountry meeting on the health, social and economic aspects of khat, Mogadishu.

Beckerleg, S., 2010. East African discourses on khat and sex. Journal of Ethnopharmacology.

Bhui, K., Warfa, N., 2010. Trauma, khat and common psychotic symptoms among Somali immigrants: A quantitative study. Journal of Ethnopharmacology.

Dessie, G., Kinlund, P., 2007. Khat expansion and forest decline in Wondo Genet, Ethiopia. Geografiska Annaler.

EMCDDA., (in press). Khat (Catha edulis): a herbal high from the Horn of Africa arrives in Europe: Implications for European policies, Lisbon: European Monitoring Centre for Drugs and Drugs Addiction.

Feyissa, A.M., Kelly, J.P., 2008. A review of the neuropharmacological properties of khat. Progress in Neuropsychopharmacology Biology Psychiatry 32 (5), 1147-1166.
Gebissa, E., 2004. Leaf of Allah: Khat \& Agricultural Transformation in Harerge, Ethiopia 1875-1991. James Currey, Ohio University Press, Oxford, Athens.

Gebissa, E., 2010. Khat in the Horn of Africa: historical perspectives and current trends. Journal of Ethnopharmacol.

GermanAgroAction. (2009). Khat. Addis Ababa: German Agro Action.

Griffiths, P., Lopez, D., Sedefov, R., Gallegos, A., Hughes, B., Noor, A., et al., 2010. Khat use and monitoring drug use in Europe: the current situation and issues for the future. Journal of Ethnopharmacology.

Hansen, P., 2010. The ambiguity of khat in Somaliland. Journal of Ethnopharmacology.

Hoffman, R., Al'Absi, M., 2010. Khat use and neurobehavioral functions: suggestions for future studies. Journal of Ethnopharmacology.

Kassim, S., Islam, S., Croucher, R., 2010. Validity and reliability of a Severity of Dependence Scale for khat (SDS-khat). Journal of Ethnopharmacology.

Klein, A., Metal, P., 2010. A good chew or good riddance-how to move forward in the regulation of khat consumption. Journal of Ethnopharmacology.

Krikorian, A.D., 1984. Kat and its use: an historical perspective. Journal of Ethnopharmacology $12,115-178$.

Milanovic, B., 2008. Qat expenditures in Yemen and Djibouti: an empirical analysis. Journal of African Economies 17, 661-687.

Odenwald, M., Hinkel, H., Schauer, E., Schauer, M., Elbert, T., Neuner, F., et al., 2009. Use of khat and posttraumatic stress disorder as risk factors for psychotic symptoms: a study of Somali combatants. Social Science and Medicine 69, 1040-1048.

Odenwald, M., Warfa, N., Bhui, K., Elbert, T., 2010. The stimulant khat-another door in the wall? A call for overcoming the barriers. Journal of Ethnopharmacology.

Randall, T., 1993. Khat abuse fuels Somali conflict, drains economy. Journal of American Medical Association 269, 12-15.

Schopen, A. (1981). Qat im Jemen. In H. Gros (Ed.), Rausch und Realität - eine Kulturgeschichte der Drogen (pp. 135-139). Stuttgart: Ernst Klett.

Shahandeh, B., Geadah, R., Tongue, A., Tongue, E., Rolli, J. (Eds.), 1983. International conference on khat: The health and socio-economic aspects of khat use, January 17-21, 1983, Antananaribo, Madagascar. Lausanne, Switzerland: International Council Against Alcohol and Addictions, ICAA.

Warfa, N., Klein, A., Bhui, K., Leavey, G., Craig, T., Stansfeld, S.A., 2007. Khat use and mental illness: a critical review. Social Science and Medicine 65., 309-318.

Warner, J., 2002. Craze: Gin and Debauchery in an Age of Reason, Toronto: Random House, 2002.

Watzl, H., Singer, M.V., 2005. Alkohol und alkoholismus: kulturgeschichtliche anmerkungen. In: Singer, M.V., Teyssen, S. (Eds.), Alkohol und Alkoholkrankheiten, 2nd ed. Springer, Berlin.

Michael Odenwald*
University of Konstanz, Fachbereich Psychologie,
P.O. BOX 5560/25, 78457 Konstanz, Germany

Axel Klein ${ }^{1}$

Centre for Health Service Studies, University of Kent, Canterbury, Kent CT27PD, UK

Nasir Warfa ${ }^{2}$

Queen Mary University of London, Barts $\mathcal{E}$ The London School of Medicine \& Dentistry, Centre for Psychiatry, Wolfson Institute of Preventive Medicine, Old Anatomy Building, London EC1M 6BQ United Kingdom

* Corresponding author. Tel.: +49 07531884621 ; fax: +497531884601 . E-mail addresses:

Michael.odenwald@uni-konstanz.de (M. Odenwald), a.klein@kent.ac.uk, axelcklein@yahoo.com (A. Klein), n.warfa@qmul.ac.uk (N.Warfa)

${ }^{1}$ Tel.: +44 01227 824090/778 8140267; fax: +4401227824054.

2 Tel: +44 0207882 2012/2021; fax: +44 02078825728 . 